\title{
Berger, G./Wasserman, J. (Hrsg.), Vetternwirtschaft, Duncker \& Humblot GmbH, 2011
}

\author{
Juergen G. Backhaus
}

Nepotism is the publication of a correspondence between Frederic II of Prussia and Louise Dorothea of Saxe Gotha, his "dear" cousin.

Frederic had started the correspondence in a letter not reproduced soliciting soldiers from Gotha and Altenburg. Gotha reluctantly complied, after five years of tense negotiations.

After Voltaire's departure from Potsdam the duchess invited him to Gotha. The castle was, however, too cold for the French philosopher to stay for the duration.

The correspondence ends with the untimely death of the duchess in 1767. The correspondence lasted from 1757 to 1763. Although it dealt with official matters, ${ }^{1}$ it was written in the form of a personal exchange between cousins.

\footnotetext{
${ }^{1}$ In the dispute over the succession in Saxony Weimar, she solicited Frederićs support-he was equally reluctant.

J. G. Backhaus ( $₫)$

Krupp Chair in Public Finance and Fiscal Sociology, University of Erfurt, Nordhäuser Strasse 63, 99089 Erfurt, Germany

e-mail: juergen.backhaus@uni-erfurt.de
} 